\title{
Ice-flow sensitivity to boundary processes: a coupled model study in the Vostok Subglacial Lake area, Antarctica
}

\author{
Malte THOMA, ${ }^{1,2}$ Klaus GROSFELD, ${ }^{2}$ Christoph MAYER, ${ }^{1}$ Frank PATTYN ${ }^{3}$ \\ ${ }^{1}$ Commission for Glaciology, Bavarian Academy of Sciences, Munich, Germany \\ ${ }^{2}$ Alfred Wegener Institute for Polar and Marine Research, Bremerhaven, Germany \\ E-mail: malte.thoma@awi.de \\ ${ }^{3}$ Département des Sciences de la Terre et de l'Environnement, Université Libre de Bruxelles, Brussels, Belgium
}

\begin{abstract}
Several hundred subglacial lakes have been identified beneath Antarctica so far. Their interaction with the overlying ice sheet and their influence on ice dynamics are still subjects of investigation. While it is known that lakes reduce the ice-sheet friction towards a free-slip basal boundary condition, little is known about how basal melting and freezing at the lake/ice interface modifies the ice dynamics, thermal regime and ice rheology. In this diagnostic study we simulate the Vostok Subglacial Lake area with a coupled full Stokes 3-D ice-flow model and a 3-D lake-circulation model. The exchange of energy (heat) and mass at the lake/ice interface increases (decreases) the temperature in the ice column above the lake by up to $10 \%$ in freezing (melting) areas, resulting in a significant modification of the highly nonlinear ice viscosity. We show that basal lubrication at the bottom of the ice sheet has a significant impact not only on the ice flow above the lake itself, but also on the vicinity and far field. While the ice flow crosses Vostok Subglacial Lake, flow divergence is observed and modelled. The heterogeneous basal-mass-balance pattern at the lake/ice interface intensifies this divergence. Instead of interactive coupling between the ice-flow model and the lake-flow model, only a single iteration is required for a realistic representation of the ice/water interaction. In addition, our study indicates that simplified parameterizations of the surface temperature boundary condition might lead to a velocity error of $20 \%$ for the area of investigation.
\end{abstract}

\section{INTRODUCTION}

Subglacial lakes are common and widespread beneath the Antarctic ice sheet. More than 370 of these lakes have been identified so far (Wright and Siegert, 2011), but just 72 exceed an area of $10 \mathrm{~km}^{2}$. The largest one, Vostok Subglacial Lake (official name according to the US Board on Geographic Names; Antarctica ID: 18528), located in East Antarctica (Fig. 1a), measures $16000 \mathrm{~km}^{2}$ (Studinger and others, 2004; Filina and others, 2008). Subglacial lakes are identified from satellite images by their surface, which is flat compared to the surrounding ice sheet. These lakes have been isolated from direct exchange with the atmosphere by several kilometers of ice for millions of years and hence provide a unique environment for potential life forms.

Drilling at Vostok station revealed that not only does melting take place at the ice base, but also water refreezes at the lake/ice interface (Jouzel and others, 1999; Siegert and others, 2001). At Vostok station a $210 \mathrm{~m}$ thick layer of accreted lake/ice was discovered between the meteoric ice and the lake's surface. Tikku and others (2004) were able to estimate the distribution of accreted ice by ice-penetrating radar feature tracking. However, until drilling into subglacial lakes (as suggested by Woodward and others, 2010) provides in situ information, numerical models are needed to quantify processes at the lake/ice interface (Williams, 2001; Mayer and others, 2003; Thoma and others, 2007, 2008a, 2009, 2010a; Woodward and others, 2010). According to Bell and others (2007), the storage capacity of subglacial lakes should be considered in ice-sheet mass-balance assessments. The role of these lakes for the subglacial hydrology is still not clear, but there are indications of an active hydrological system underneath the ice sheet, which affects the general ice dynamics (Wingham and others, 2006; Fricker and others, 2007; Bell and others, 2011) and might trigger the onset of fast-flowing ice streams by basal lubrication (Bell and others, 2007; Kohler, 2007; Stearns and others, 2008). The ice flow depends on the temperature-dependent viscosity of the ice body. The viscosity is modified by basal melting and freezing, which induce vertical velocities at the ice base on the order of centimeters per year. A coupled modelling approach with an idealized setting has been applied recently in order to investigate the interaction of subglacial lakes with the overlying ice sheet (Thoma and others, 2010b).

In this study we take a further step and investigate the impact of different forcings, such as surface temperature, basal mass exchange and basal friction, on the ice flow in the area of Vostok Subglacial Lake.

\section{BOUNDARY CONDITIONS AND MODEL SET-UP}

In order to investigate the area around Vostok Subglacial Lake in a numerical model study, surface elevation and bedrock for the entire model domain were taken from the BEDMAP dataset (Lythe and others, 2001). To acquire a more realistic representation of the Vostok Subglacial Lake domain, we merged the most up-to-date regional bedrock geometry model by Filina and others (2008) into the continental BEDMAP model (Figs $1 \mathrm{~b}$ and $2 \mathrm{a}$ and $\mathrm{b}$ ).

The surface accumulation rate is given by Arthern and others (2006). The initial temperature distribution within the ice is calculated according to Robin (1955), based on a spatially varying surface temperature and the basal pressure-dependent freezing point of the ice-sheet 

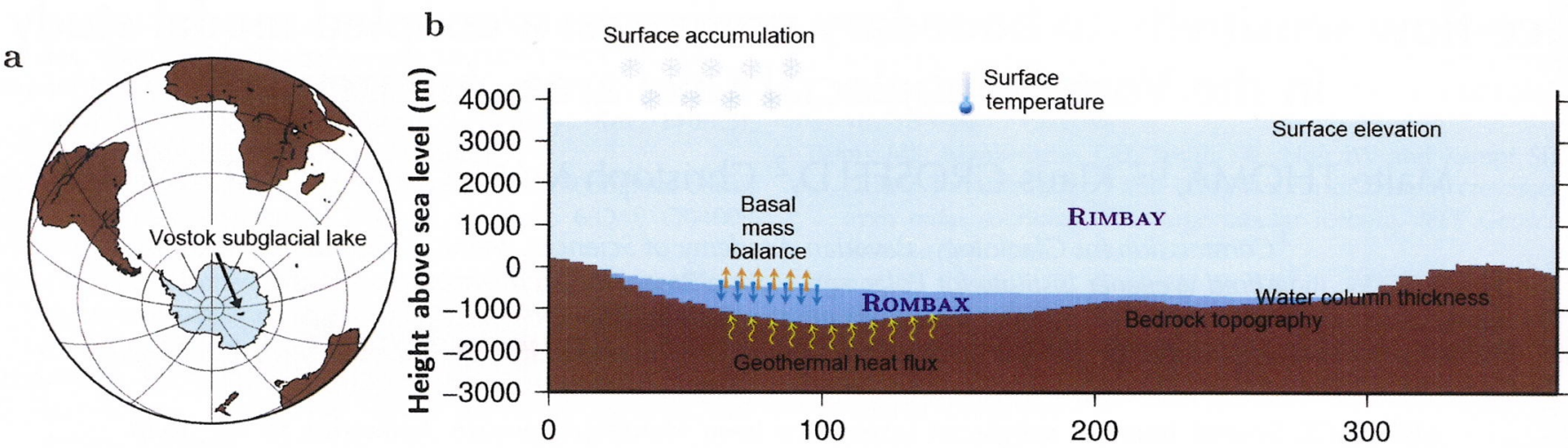

Distance $(\mathrm{km})$

Fig. 1. (a) Position of Vostok Subglacial Lake; the exact geographical location, with respect to longitude and latitude, is given in Figure 8a. (b) Cross section through the lake along the profile shown in Figure $4 a$, indicating numerical model domains and boundary conditions.

base. Three different surface-temperature fields are applied (Fig. 3): a simple latitude/height parameterization after Huybrechts (1992), a dataset based on satellite infrared measurements (Comiso, 2000; Le Brocq and others, 2010) and a dataset derived from borehole measurements (Wang and Hou, 2009). The basal geothermal heat flux is prescribed according to Shapiro and Ritzwoller (2004).

Ice flow across subglacial lakes and bedrock differs significantly in basal friction and basal mass balance. Basal friction is parameterized by a scalar friction coefficient, $\beta^{2}$ (MacAyeal, 1993; Pattyn, 2003, 2008), which relates basal velocity, $\overrightarrow{v_{\mathrm{b}}}$, to basal drag: $\overrightarrow{\tau_{\mathrm{b}}}=\beta^{2} \overrightarrow{v_{\mathrm{b}}}$. Above subglacial lakes, a free-slip condition, $\beta^{2}=0$, allows sliding. Above bedrock, $\beta^{2}=25000 \mathrm{~Pa} \mathrm{am}^{-1}$ corresponds to a typical basal frictional stress of $\sim 100 \mathrm{kPa}$ (Paterson, 1994) if a velocity of $\sim 4 \mathrm{ma}^{-1}$ is assumed. The basal mass balance (Fig. 2c) is given by the lake-flow model ROMBAX (Revisited Ocean Model based on Bryan and Cox; Thoma and others, 2010a). This general circulation model calculates the water circulation and the melting and freezing rates at the lake/ice boundary considering the pressure-dependent freezing point and conservation of heat according to Holland and Jenkins (1999). All boundary conditions applied to force the ice-flow model RIMBAY (Revised Ice sheet Model Based on frAnk PattYn; Thoma and others, 2010b) are summarized in Table 1 and indicated in Figure 1.

The whole model domain is shown in Figure 2a. The ice divide, from where the ice approaches Vostok Subglacial Lake, is included in the model domain, which renders specific lateral boundary conditions unnecessary. The horizontal resolution of RIMBAY is $5 \mathrm{~km}$; in the vertical, 40 terrain-following layers are applied. The time-step is dynamically adjusted according to the Courant-FriedrichsLewy (CFL) condition. The initial flow field starts from rest, and the model runs for 200000 years in a shallow-ice approximation (SIA) mode, until a preliminary steady state of the velocity and temperature field is reached. After an additional 50000 model years, and the application of full Stokes physics (e.g. Pattyn, 2008), the model achieves steady state. For this study the ice model runs in a diagnostic mode,
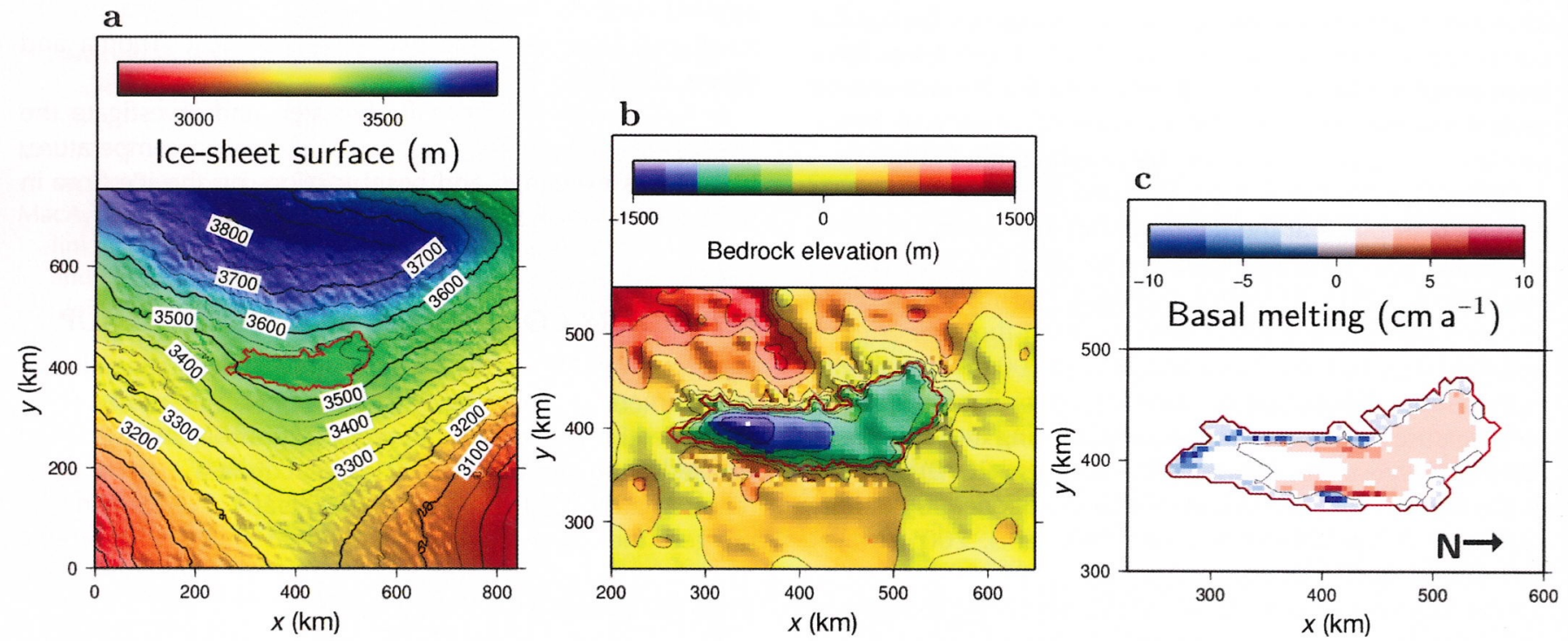

Fig. 2. (a) Ice-sheet surface and (b) bedrock elevation in the Vostok Subglacial Lake area. Data according to Lythe and others (2001), improved according to Filina and others (2008). The solid red line indicates the lake's shoreline, determined by satellite imagery. (c) Applied basal mass balance according to Thoma and others (2010a). Negative values represent basal freezing. The arrow indicates geographic north. The full model domain is shown in (a); (b) and (c) show regions only around the lake to allow details to be distinguished. 
a

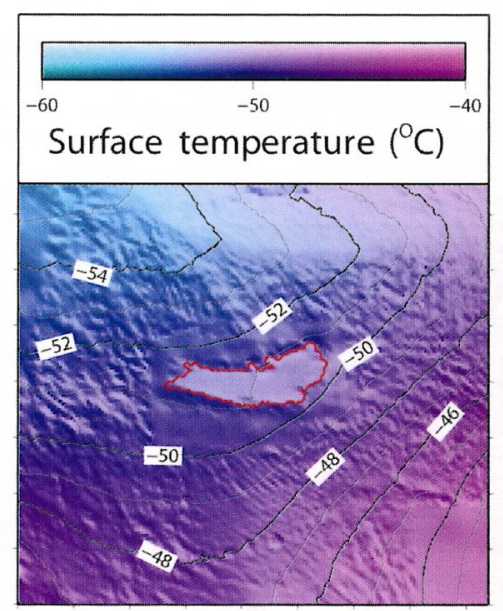

b

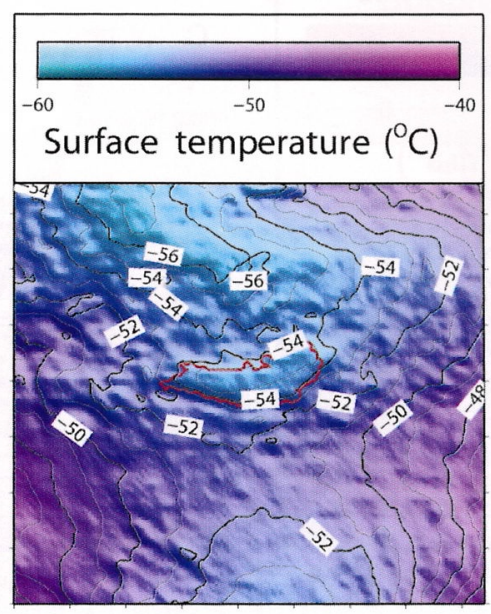

C

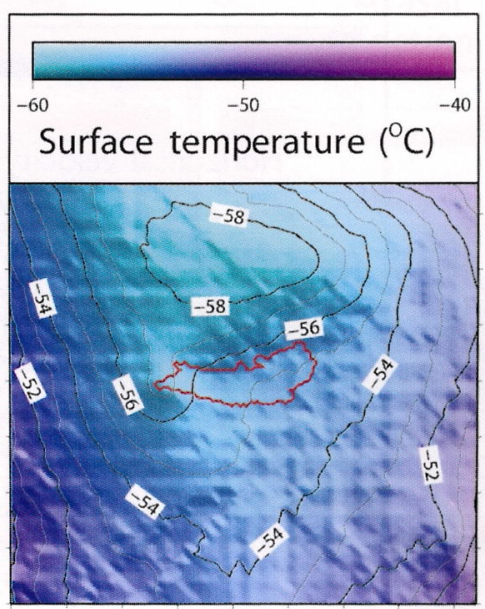

Fig. 3. Applied surface temperatures according to (a) Huybrechts (1992), (b) Comiso (2000) and (c) Wang and Hou (2009).

keeping ice thickness, bedrock, lake volume and groundingline position constant.

\section{RESULTS \\ General flow and temperature regime above Vostok Subglacial Lake}

Our modelled surface flow field across Vostok Subglacial Lake (Fig. 4a) is in agreement with the modelling results of Pattyn and others (2004). It shows a consistent pattern, with flow directions similar to those indicated by the radar-image feature tracking of Tikku and others (2004) and a Vostok flowline modelled by Salamatin and others (2009). Our modelled ice-flow velocity at Vostok station of $\sim 4.0 \mathrm{~m} \mathrm{a}^{-1}$ fits within the ice-flow velocities observed $\left(1.9-4.2 \mathrm{~m} \mathrm{a}^{-1}\right)$ by Kwok and others (2000), Bell and others (2002), Tikku and others (2004) and Wendt and others (2005). Therefore, we consider the model realistic enough to investigate the impact of different boundary forcings with respect to the flow field.

Upstream of the lake, the modelled velocity ranges from $\sim 3.0$ to $3.5 \mathrm{~m} \mathrm{a}^{-1}$. Across the lake, the frictionless bottom results in a general velocity acceleration. In the lake's center, only a slight increase to $\sim 3.6 \mathrm{~m} \mathrm{a}^{-1}$ is modelled, but in the northern and southern parts of the lake the velocity increases to up to 4.6 and $4.1 \mathrm{~m} \mathrm{a}^{-1}$, respectively, are significant. The ice flow over Vostok Subglacial Lake diverges. In particular, at the southern tip of the lake the flow is significantly diverted southward. These deflections correspond to the increased velocities at both ends of the lake. However, the reasons for these velocity increases are different. In the south, where freezing is strongest (Fig. 2c), ascending isotherms result in warmer ice (Fig. 5) and hence in a reduced viscosity. Therefore, velocities are increased at the southern end of the lake. Beyond the lake, without basal freezing, the basal temperature cools down again and hence the velocities decrease to their former magnitude. In contrast, the increased ice-surface gradient northeast of the lake (Fig. 2a) results in a significant flow acceleration downstream of the lake, to velocities of up to $6.5 \mathrm{ma}^{-1}$ This flow is channelled by a subglacial trough in this area (Fig. 2b). The absence of basal friction over the lake results in ice-shelf-like flow in this area whereby ice over the northern part of the lake is dragged by the fast-flowing ice beyond the lake. These findings are consistent with those of Bell and others (2007), who concluded that subglacial lakes initiate and maintain rapid ice flow through either active modification of the basal thermal regime of the ice sheet by lake accretion or through scouring bedrock channels in periodic drainage events.

Additional validation of the model results can be achieved by comparing the vertical temperature profile in the southern part of the lake with measurements from the Vostok station borehole (e.g. Salamatin and others, 1994; Lipenkov and others, 2004). According to our modelling, only the surface temperature forcing of Wang and Hou (2009) is able to reproduce the observed temperatures in the upper part of the ice sheet. The two other available surface temperature datasets (Huybrechts, 1992; Comiso, 2000) result in too warm ice in the upper ice column. At the base the

Table 1. Summary of applied boundary conditions

Field

General surface elevation and bedrock

Improved surface elevation, bedrock and water column thickness for the Vostok Subglacial Lake area

Surface accumulation

Geothermal heat flux

Surface temperature

Basal mass balance
Source

BEDMAP (Lythe and others, 2001)

Filina and others (2008)

Arthern and others (2006)

Shapiro and Ritzwoller (2004)

Huybrechts (1992); Comiso (2000); Wang and Hou (2009)

Interactively coupled according to Thoma and others $(2010 a, b)$ 

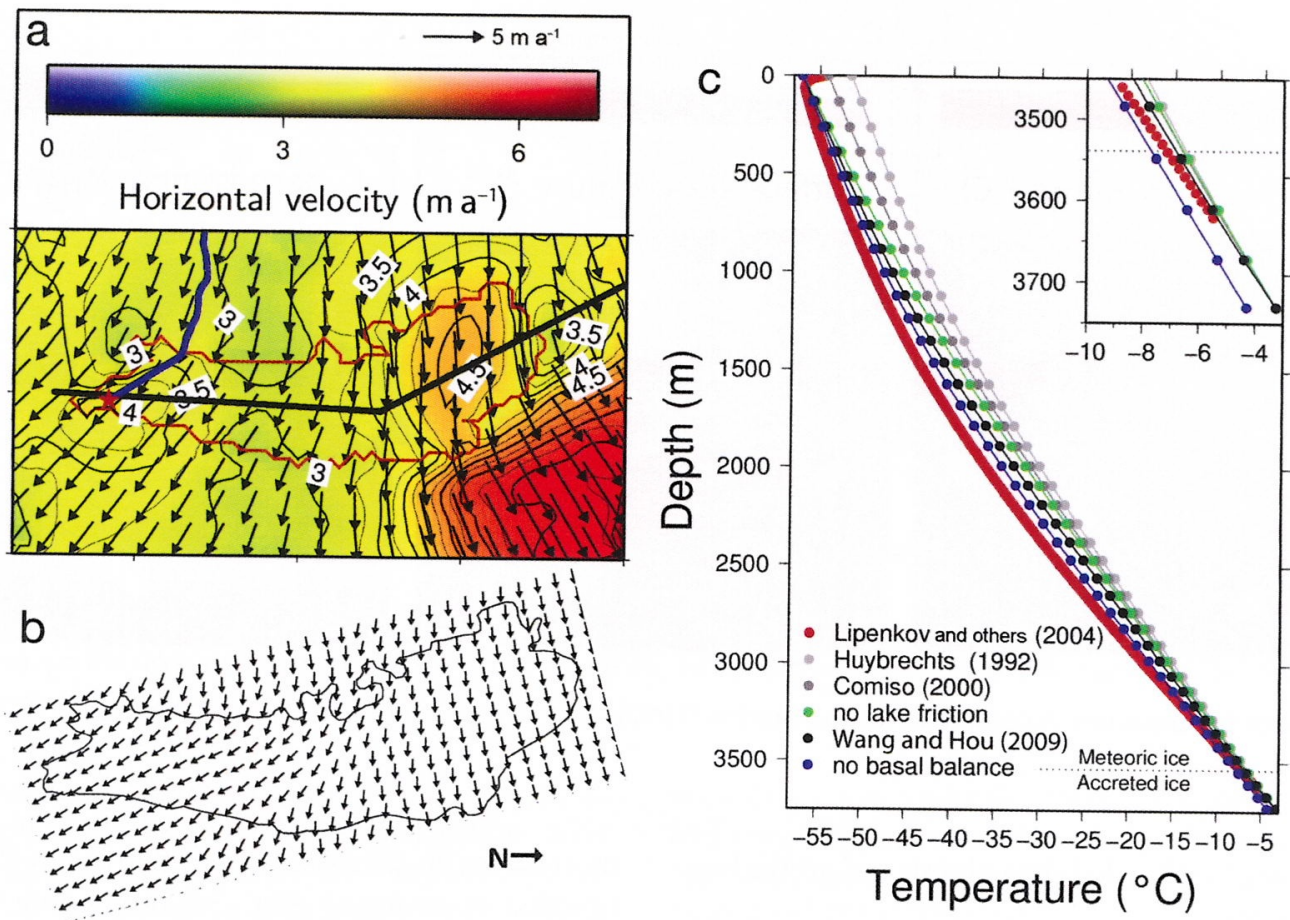

Fig. 4. (a) Modelled averaged horizontal velocities for surface temperatures according to Wang and Hou (2009). The red line indicates the lake boundary, the blue line the Vostok flowline of Salamatin and others (2009) ending at Vostok station (red star). The black line is the position of a temperature cross section. (b) Flow field direction according to Tikku and others (2004). (c) Observed (Lipenkov and others, 2004) and modelled vertical temperature profiles according to different forcings near Vostok station.

pressure-dependent melting point defines the basal temperature. Although measurements do not reach down to the lake/ice interface, the model results agree well with the available profile. In $\sim 2000 \mathrm{~m}$ depth the modelled temperature (forced with the surface-temperature data of Wang and Hou, 2009) is up to $2{ }^{\circ} \mathrm{C}$ above the in situ temperature. This deviation may result from uncertainties of the modelled flow field, the assumed upstream surface temperatures and/or accumulation rate, or variations in the history of these parameters. Based on an assumed average ice-flow velocity of $2 \mathrm{~m} \mathrm{a}^{-1}$ and a distance of $200 \mathrm{~km}$ from the ice divide (Figs 2a and 4a), variations of the surface boundary conditions during the last 100000 years would be necessary to model a more realistic temperature profile. However, for the scope of this study we consider the

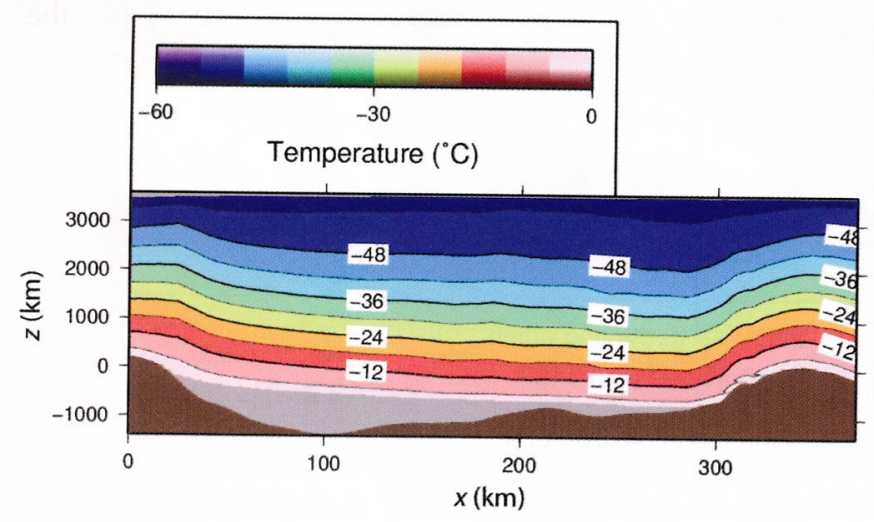

Fig. 5. Temperature cross section along the track shown in Figure 4a. modelled flow- and temperature distribution sufficient under constant surface boundary conditions.

\section{Impact of different forcings}

We investigate the sensitivity of the ice flow above Vostok Subglacial Lake according to the impact of different boundary conditions, namely surface temperature, basal mass balance and basal sliding. All parameters have significant impact on the ice-flow regime. The impact of other boundary conditions (e.g. geothermal heat flux and accumulation) on the ice dynamics is not investigated in this study.

\section{Surface temperature}

A modified surface temperature field has a significant impact on the velocity, in particular in the already fast-flowing areas of the northern and southern part of the lake itself, as well as northeast of the lake (Figs 6a and b and 7a and b). Compared to the reference forcing (Wang and Hou, 2009), the surface temperatures according to Huybrechts (1992) and Comiso (2000) are $\sim 5^{\circ}$ and $2^{\circ}$ warmer, respectively (Fig. 7a and b). Hence the temperature-dependent viscosity decreases, which corresponds to a velocity increase of up to $20 \%$ for these warmer surface temperature forcings. In addition, both warmer surface forcings induce a stronger southward deflection of the flow over the lake.

\section{Basal mass balance}

To investigate the influence of the basal mass balance on the flow regime, we present results with neglected basal melting and freezing above the lake in Figures $6 \mathrm{c}$ and $7 \mathrm{c}$. The spatially varying basal mass balance has a heterogeneous impact on the flow. Basal freezing in the south (Fig. 2c) 


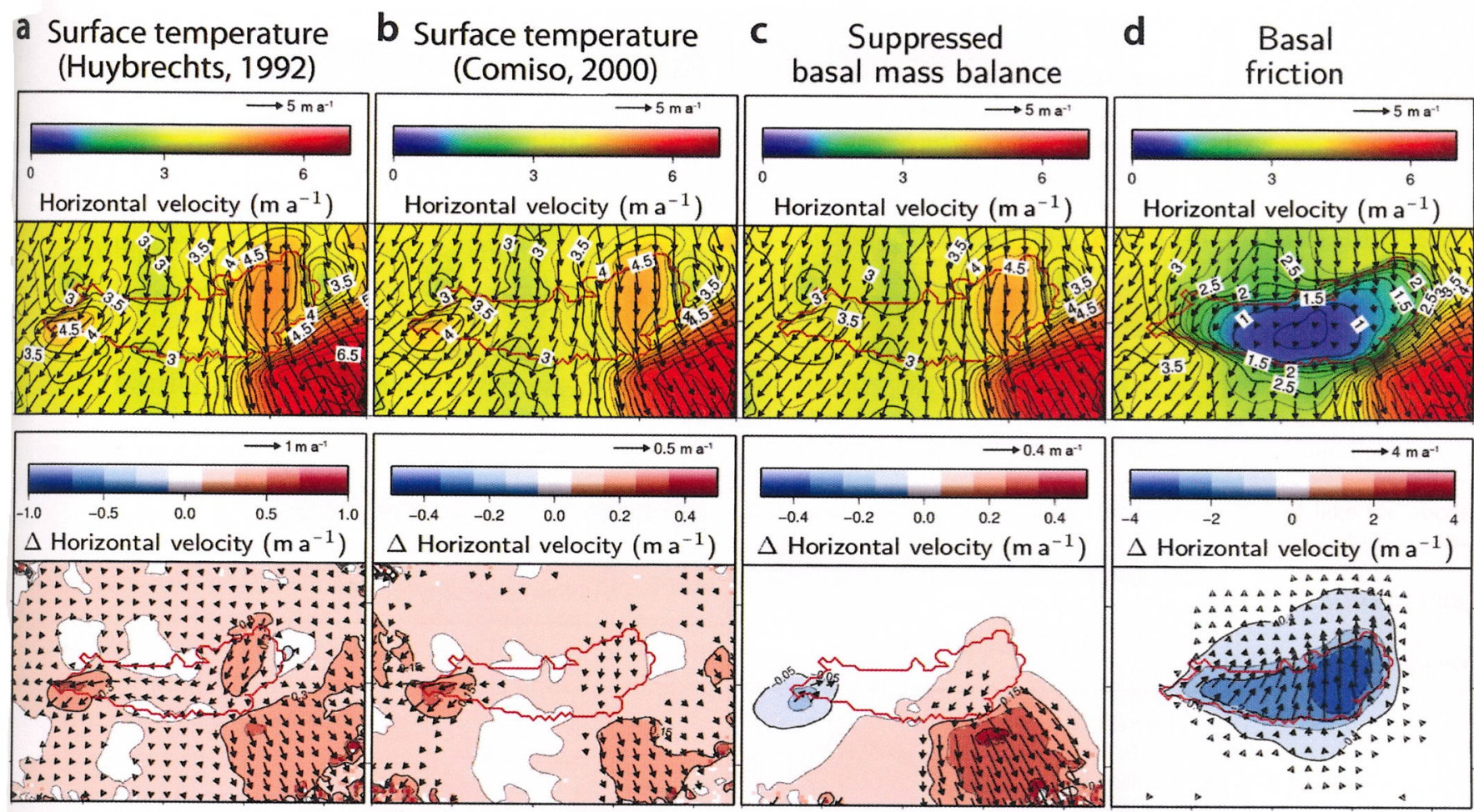

Fig. 6. (Top) Modelled mean horizontal velocities and (bottom) differences between this and the reference models of Figure 4 for surface temperature forcings according to (a) Huybrechts (1992) and (b) Comiso (2000); also for (c) a model with suppressed basal mass balance at the lake/ice interface and (d) a model with basal friction at the lake/ice interface.

induces upward vertical velocities. Hence the ice is warmer in regions of freezing. In contrast, basal melting in the north results in downward advection of colder surface ice; consequently the ice is colder in this region compared to the control run. Note that for consistency Figures $6 \mathrm{c}$ and $7 \mathrm{c}$ indicate the effect of the ignored basal mass balance; hence the effect of the varying basal mass balance itself has the opposite sign. The modelled velocity (Fig. 6c) is again closely linked to the temperature-dependent viscosity. Therefore, freezing in the south increases the velocity and intensifies the southward deflection of the flow. In contrast, the extended melting in the north reduces the horizontal velocity. Both effects have a significant impact on the downstream flow far beyond the lake's edge. In summary, the spatially varying basal-mass-balance pattern intensifies the flow divergence above Vostok Subglacial Lake.

\section{Basal sliding}

If basal sliding at the lake/ice interface is ignored, the reduced surface gradient over the lake significantly decreases the flow velocity (Fig. 6d) in this diagnostic model set-up. However, this effect is not limited to the lake itself. In particular, a significant $\left(>0.5 \mathrm{ma}^{-1}\right)$ velocity decrease is modelled upstream. We conclude that subglacial lakes influence the ice flow in the order of the lake's dimension. The reduced horizontal flow results in a longer transition time of the ice across the lake. This explains the twofold impact on the temperature (Fig. 7d). First, basal freezing (in the south) and melting (in the north) modifies the vertical velocity. This results in advection of warmer ice upwards and colder ice downwards, as discussed above. Second, the relatively higher surface temperatures (compared to upstream) give rise to a slight warming of the upper part of the ice column even
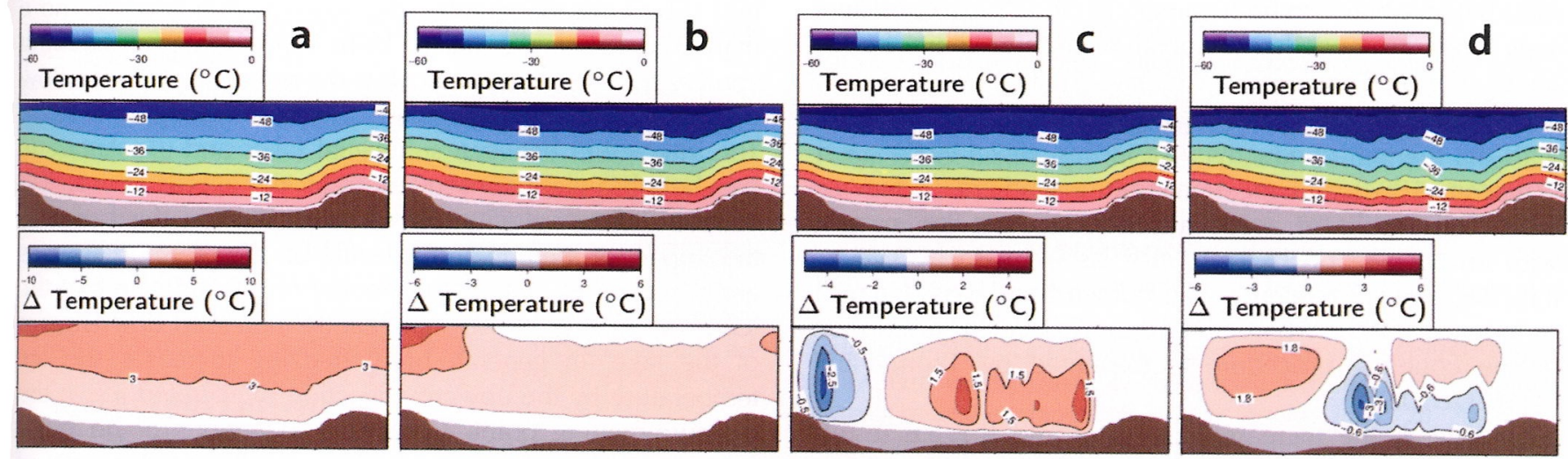

Fig. 7. Modelled temperature profile along the track indicated in Figure 4a across Vostok Subglacial Lake (upper panel) and differences between this and the reference model (lower panel; Fig. 4c) for the same model forcings as in Figure 6a-d. 

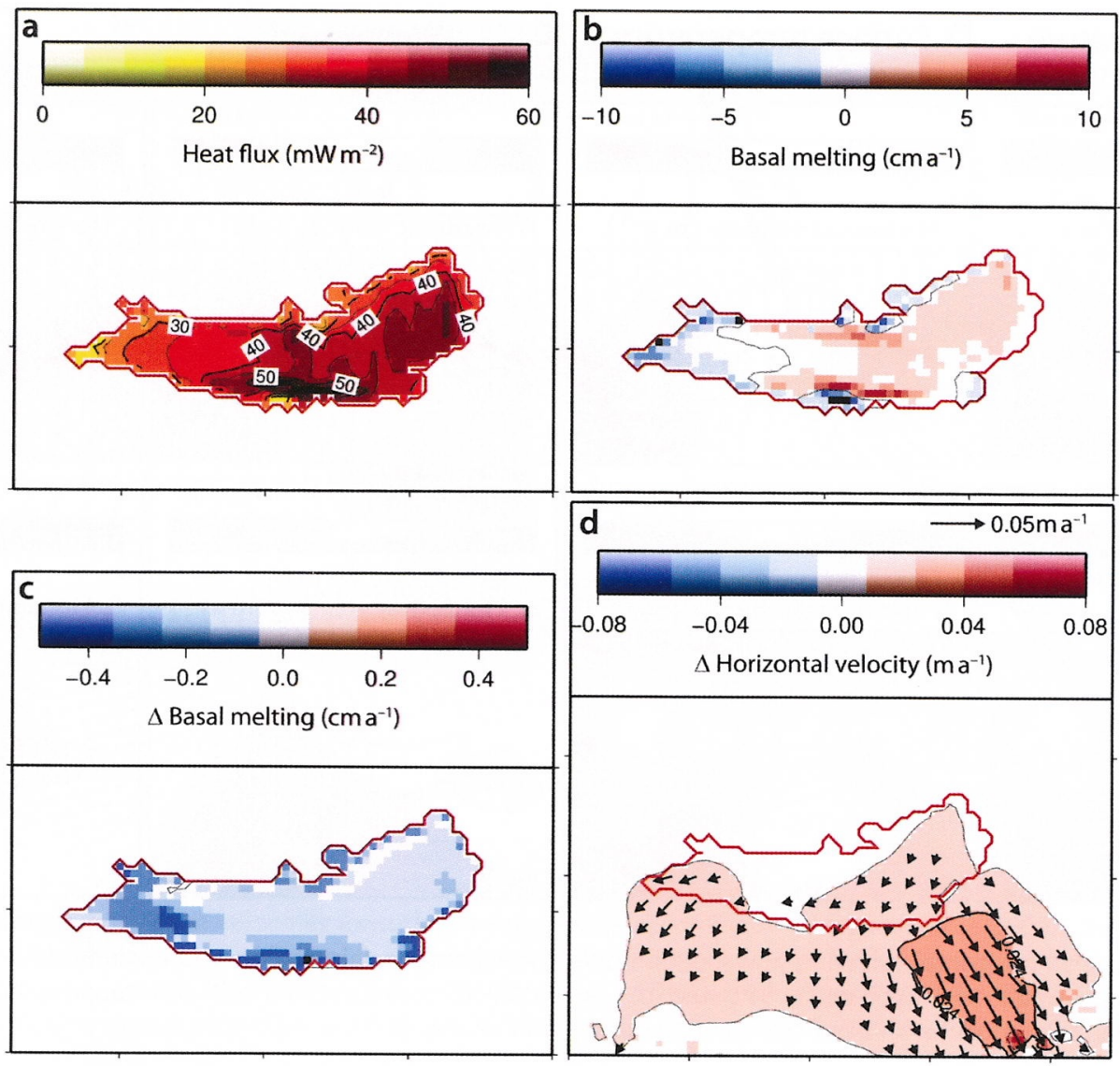

Fig. 8. (a) Heat flux into the ice sheet, according to the output of the ice-flow model RIMBAY, applied as an input boundary condition for the lake-flow model ROMBAX. (b) Basal-mass-balance boundary condition for RIMBAY according to the coupled system and (c) difference between Figures $2 \mathrm{c}$ and $8 \mathrm{~b}$. (d) Difference between the vertically averaged horizontal flow of the uncoupled (Fig. 4a) and coupled models (slightly extended map to demonstrate the downstream effect).

in the north. This warming counteracts the freezing-induced cooling of the lower part of the ice column.

\section{Impact of a coupled ice-sheet/lake system}

The basal-mass-balance boundary condition (Fig. 2c) is derived from the model output of the lake-flow model ROMBAX, which is partly forced by the heat flux into the overlying ice sheet. Until now this was assumed to be constant, $33 \mathrm{~mW} \mathrm{~m}^{-2}$, where ice melts and zero where ice freezes (Thoma and others, 2008b). However, coupling ROMBAX with the ice-flow model RIMBAY allows modelling of the exchange parameters heat flux into the ice and basal mass balance between both numerical models in a consistent way. From the modelled temperature profile within the ice above Vostok Subglacial Lake (Fig. 5) the heat flux into the ice can be estimated according to $Q_{\text {ice }}=c_{p} \mathrm{~d} T / \mathrm{d} h$, with the thermal conductivity of ice $c_{p}=2.1 \mathrm{~W} \mathrm{~K}^{-1} \mathrm{~m}^{-1}$ (Paterson, 1994) and the temperature gradient at the ice base. This results in a spatially varying heat-flux pattern with an average of $38.9 \mathrm{~mW} \mathrm{~m}^{-2}$ as input for ROMBAX (Fig. 8a), and subsequently in a refined basal mass balance as input for RIMBAY (Fig. 8b and c). A detailed description of the coupling procedure is presented by Thoma and others (2010b)..

In general, the increased heat flux into the ice results in a decrease of the melting area by $7 \%$ (from $\sim 1.15 \times$ $10^{4} \mathrm{~km}^{2}$ to $1.07 \times 10^{4} \mathrm{~km}^{2}$ ) and an increase of the freezing area by $35 \%$ (from $5.28 \times 10^{3} \mathrm{~km}^{2}$ to $7.12 \times 10^{3} \mathrm{~km}^{2}$ )
(Fig. $8 \mathrm{~b}$ and c). Consequently, the total basal melting reduces from $0.0910 \mathrm{~km}^{3} \mathrm{a}^{-1}$ to $0.0177 \mathrm{~km}^{3} \mathrm{a}^{-1}$, leading to slightly warmer basal ice. However, the flow field changes only slightly with the interactive coupling of the ice- and lake-flow models. The ice flow increases by less than $\sim 0.5 \%$ (Fig. $8 \mathrm{~d}$ ) above the lake and in its vicinity.

\section{DISCUSSION}

The recent view of basal processes at the base of the Antarctic ice sheet suggests a widespread occurrence of liquid water (e.g. Pattyn, 2010; Bell and others, 2011). This water drains into subglacial topographic depressions, indicated by more than 370 subglacial lakes. With our coupled modelling approach, we explicitly calculate the response of the ice flow on melting and freezing in the area of Vostok Subglacial Lake. The interaction between subglacial lakes and the Antarctic ice sheet has clear consequences for the ice dynamics. The increased flow velocity due to lubrication at the bed and the impact of melting and freezing on the thermodynamics are of great importance. Our model results indicate that the ice-flow velocity is also significantly increased downstream of the lake. In general, basal freezing increases the ice temperature by the upward advection of accreted ice at the pressure-melting point. Compared to regions of no basal freezing, this warming results in a significant decrease of the ice viscosity. According to Paterson (1994, p. 97), the flow parameter, $A$, is modified by $\sim 25 \%$ if we assume 
an average temperature of $T \approx-30^{\circ} \mathrm{C}$ and a deviation of $\Delta T \approx 2{ }^{\circ} \mathrm{C}$. Hence the ice flow in warmer areas is slightly more decoupled from the surrounding flow field, and the local surface gradient gains more relevance for the flow direction. However, ice-sheet models, which neglect basal processes, misinterpret the impact of basal temperature because basal melting cools the ice while basal freezing leads to higher ice temperatures. We strongly recommend improving the treatment of subglacial hydrology in further model investigations. A prognostic version of the presented model might indicate that only the consideration of the complex basal-mass-balance pattern at the lake/ice interface is able to maintain the observed southward surface slope across Vostok Subglacial Lake, which would otherwise level (Pattyn and others, 2004). Interaction of ice sheets with subglacial water systems is not limited to subglacial lakes; in the transition zone between ice sheets and ice shelves (the grounding line), this interaction also plays a crucial role (e.g. Vieli and Payne, 2005; Schoof, 2007; Docquier and others, 2011; Favier and others, 2011). In future work we will expand our model to address these effects at the grounding line and over ice shelves and ice rises.

\section{ACKNOWLEDGEMENTS}

This work was funded by the German Research Foundation (DFG) through grant MA3347/2-1. This work was supported by funding from the ice2sea programme from the European Union 7th Framework Programme, grant No. 226375. This is ice2sea contribution No. 040. We thank Roland Warner, Heinrich Miller and Jürgen Determann for helpful discussions, Yetang Wang for providing his surface temperature data, Andrey Salamatin for providing the data of the Vostok station flowline track, Vladimir Lipenkov for providing measured temperature profiles, and Andrea Bleyer and Stefanie Klebe for proofreading.

\section{REFERENCES}

Arthern RJ, Winebrenner DP and Vaughan DG (2006) Antarctic snow accumulation mapped using polarization of $4.3 \mathrm{~cm}$ wavelength microwave emission. J. Geophys. Res., 111(D6), D06107 (doi: 10.1029/2004JD005667)

Bell RE, Studinger M, Tikku AA, Clarke GKC, Gutner MM and Meertens C (2002) Origin and fate of Lake Vostok water frozen to the base of the East Antarctic ice sheet. Nature, 416(6878), 307-310 (doi: 10.1038/416307a)

Bell RE, Studinger M, Shuman CA, Fahnestock MA and Joughin I (2007) Large subglacial lakes in East Antarctica at the onset of fast-flowing ice streams. Nature, 445(7130), 904-907 (doi: 10.1038/nature05554)

Bell RE and 11 others (2011) Widespread persistent thickening of the East Antarctic Ice Sheet by freezing from the base. Science, 331(6024), 1592-1595 (doi: 10.1126/science.1200109)

Comiso JC (2000) Variability and trends in Antarctic surface temperatures from in situ and satellite infrared measurements. J. Climate, 13(10), 1674-1696 (doi: 10.1175/15200442(2000)013<1674:VATIAS > 2.0.CO;2)

Docquier D, Perichon L and Pattyn F (2011) Representing grounding line dynamics in numerical ice sheet models: recent advances and outlook. Surv. Geophys., 32(4-5), 417-435 (doi: 10.1007/s10712-011-9133-3)

Favier L, Gagliardini O, Durand G and Zwinger T (2011) A threedimensional full Stokes model of the grounding line dynamics: effect of a pinning point beneath the ice shelf. Cryos. Discuss., 5(4), 1995-2033 (doi: 10.5194/tcd-5-1995-2011)
Filina IY, Blankenship DD, Thoma M, Lukin VV, Masolov VN and Sen MK (2008) New 3D bathymetry and sediment distribution in Lake Vostok: implication for pre-glacial origin and numerical modeling of the internal processes within the lake. Earth Planet. Sci. Lett., 276(1-2), 106-114 (doi: 10.1016/j.epsl.2008.09.012)

Fricker HA, Scambos T, Bindschadler R and Padman L (2007) An active subglacial water system in West Antarctica mapped from space. Science, 315(5818), 1544-1548 (doi: 10.1126/science.1136897)

Holland DM and Jenkins A (1999) Modeling thermodynamic ice-ocean interactions at the base of an ice shelf. J. Phys. Oceanogr., 29(8), 1787-1800 (doi: 10.1175/15200485(1999)029<1787:MTIOIA > 2.0.CO;2)

Huybrechts P (1992) The Antarctic ice sheet and environmental change: a three-dimensional modelling study. Ber. Polarforsch. 99

Jouzel J and 9 others (1999) More than $200 \mathrm{~m}$ of lake ice above subglacial Lake Vostok, Antarctica. Science, 286(5447), 21382141

Kohler J (2007) Glaciology: lubricating lakes. Nature, 445(7130), 830-831 (doi: 10.1038/445830a)

Kwok R, Siegert MJ and Carsey FD (2000) Ice motion over Lake Vostok, Antarctica: constraints on inferences regarding the accreted ice. J. Glaciol., 46(155), 689-694 (doi: 10.3189/172756500781832710)

Le Brocq AM, Payne AJ and Vieli A (2010) An improved Antarctic dataset for high resolution numerical ice sheet models (ALBMAP v1). Earth Syst. Sci. Data, 2(2), 247-260 (doi: 10.5194/essdd-3-195-2010)

Lipenkov VYa, Shibayev Y, Salamatin AN, Ekaykin AA, Vostretsov RN and Preobrazhenzkaya AV (2004) Sovremennye klimaticheskie izmeneniya, zaregistrirovannye $v$ variatsiyah temperatury verhnego 80-metrovogo sloya lednikovoy tolshchi na stantsii Vostok [Current climatic changes recorded in the temperature variations in the upper $80 \mathrm{~m}$ layer of the glacial strata at Vostok station]. Mater. Glyatsiol. Issled./Data Glaciol. Stud. 97, 44-56

Lythe MB, Vaughan DG and BEDMAP consortium (2001) BEDMAP: a new ice thickness and subglacial topographic model of Antarctica. J. Geophys. Res., 106(B6), 11 335-11 351

MacAyeal DR (1993) A tutorial on the use of control methods in ice-sheet modeling. J. Glaciol., 39(131), 91-98

Mayer C, Grosfeld K and Siegert MJ (2003) Salinity impact on water flow and lake ice in Lake Vostok, Antarctica. Geophys. Res. Lett., 30(14), 1767 (doi: 10.1029/2003GL017380)

Paterson WSB (1994) The physics of glaciers, 3rd edn. Elsevier, Oxford

Pattyn F (2003) A new three-dimensional higher-order thermomechanical ice-sheet model: basic sensitivity, ice stream development, and ice flow across subglacial lakes. J. Geophys. Res., 108(B8), 2382 (doi: 10.1029/2002JB002329)

Pattyn F (2008) Investigating the stability of subglacial lakes with a full Stokes ice-sheet model. J. Glaciol., 54(185), 353-361 (doi: 10.3189/002214308784886171)

Pattyn F (2010) Antarctic subglacial conditions inferred from a hybrid ice sheet-ice stream model. Earth Planet. Sci. Lett., 295(34), 451-461 (doi: 10.1016/j.epsl.2010.04.025)

Pattyn F, De Smedt B and Souchez R (2004) Influence of subglacial Vostok lake on the regional ice dynamics of the Antarctic ice sheet: a model study. J. Glaciol., 50(171), 583-589 (doi: 10.3189/172756504781829765)

Robin GdeQ (1955) Ice movement and temperature distribution in glaciers and ice sheets. J. Glaciol., 2(18), 523-532

Salamatin AN, Lipenkov VY and Blinov KV (1994) Vostok (Antarctica) climate record time-scale deduced from the analysis of a borehole-temperature profile. Ann. Glaciol., 20, 207-214

Salamatin AN, Tsyganova EA, Popov SV and Lipenkov VY (2009) Ice flow line modeling in ice core data interpretation: Vostok Station (East Antarctica). In Hondoh T ed. Physics of ice core records, Volume 2. Hokkaido University Press, Sapporo, Japan, 167-194 
Schoof C (2007) Ice sheet grounding line dynamics: steady states, stability, and hysteresis. J. Geophys. Res., 112(F3), F03S28 (doi: 10.1029/2006JF000664)

Shapiro NM and Ritzwoller MH (2004) Inferring surface heat flux distribution guided by a global seismic model: particular application to Antarctica. Earth Planet. Sci. Lett., 223(1-2), 213224 (doi: 10.1016/j.epsl.2004.04.011)

Siegert MJ and 6 others (2001) Physical, chemical and biological processes in Lake Vostok and other Antarctic subglacial lakes. Nature, 414(6864), 603-609 (doi: 10.1038/414603a)

Stearns LA, Smith BE and Hamilton GS (2008) Increased flow speed on a large East Antarctic outlet glacier caused by subglacial floods. Nature Geosci., 1(12), 827-831 (doi: 10.1038/ngeo356)

Studinger M, Bell RE and Tikku AA (2004) Estimating the depth and shape of Lake Vostok's water cavity from aerogravity data. Geophys. Res. Lett., 31(12), L12401 (doi: 10.1029/2004GL019801)

Thoma M, Grosfeld K and Mayer C (2007) Modelling mixing and circulation in subglacial Lake Vostok, Antarctica. Ocean Dyn., 57(6), 531-540 (doi: 10.1007/s10236-007-0110-9)

Thoma M, Grosfeld K and Mayer C (2008a) Modelling accreted ice in subglacial Lake Vostok, Antarctica. Geophys. Res. Lett., 35(11), L11504 (doi: 10.1029/2008GL033607)

Thoma M, Mayer C and Grosfeld K (2008b) Sensitivity of subglacial Lake Vostok's flow regime on environmental parameters. Earth Planet. Sci. Lett., 269(1-2), 242-247 (doi: 10.1016/j.epsl.2008.02.023)

Thoma M, Grosfeld K, Filina I and Mayer C (2009) Modelling flow and accreted ice in subglacial Lake Concordia, Antarctica. Earth Planet. Sci. Lett., 286(1-2), 278-284 (doi: 10.1016/j.epsl.2009.06.037)

Thoma M, Grosfeld K, Smith AM and Mayer C (2010a) A comment on the Equation of State and the freezing point equation with respect to subglacial lake modelling. Earth Planet. Sci. Lett., 294(1-2), 80-84 (doi: 10.1016/j.epsl.2010.03.005)
Thoma M, Grosfeld K, Mayer C and Pattyn F (2010b) Interaction between ice sheet dynamics and subglacial lake circulation: a coupled modelling approach. Cryosphere, 4(1), 1-12 (doi: 10.5194/tc-4-1-2010)

Tikku AA, Bell RE, Studinger M and Clarke GKC (2004) Ice flow field over Lake Vostok, East Antarctica, inferred by structure tracking. Earth Planet. Sci. Lett., 227(3-4), 249-261 (doi: 10.1016/j.epsl.2004.09.021)

Vieli A and Payne AJ (2005) Assessing the ability of numerical ice sheet models to simulate grounding line migration. J. Geophys. Res., 110(F1), F01003 (doi: 10.1029/2004JF000202)

Wang Y and Hou S (2009) A new interpolation method for Antarctic surface temperature. Progr. Natur. Sci., 19(12), 1843-1849 (doi: 10.1016/j.pnsc.2009.07.012)

Wendt A and 9 others (2005) The response of the subglacial Lake Vostok, Antarctica, to tidal and atmospheric pressure forcing. Geophys. J. Int., 161(1), 41-49 (doi: 10.1111/j.1365246X.2005.02575.x)

Williams MJM (2001) Application of a three-dimensional numerical model to Lake Vostok: an Antarctic subglacial lake. Geophys Res. Lett., 28(3), 531-534

Wingham DJ, Siegert MJ, Shepherd A and Muir AS (2006) Rapid discharge connects Antarctic subglacial lakes. Nature, 440(7087), 1033-1036 (doi: 10.1038/nature04660)

Woodward J and 9 others (2010) Location for direct access to subglacial Lake Ellsworth: an assessment of geophysical data and modeling. Geophys. Res. Lett., 37(11), L11501 (doi: 10.1029/2010GL042884)

Wright A and Siegert MJ (2011) The identification and physiographical setting of Antarctic subglacial lakes: an update based on recent discoveries. In Siegert MJ, Kennicutt $\mathrm{MCl}$ and Bindschadler RA eds. Antarctic subglacial aquatic environments. American Geophysical Union, Washington, DC, $9-26$ 